\title{
The Relationship Of Rewarding With Work Motivation Of Honorary Nurses
}

\author{
Nadia Alfira ${ }^{1}$, Safruddin ${ }^{*}$ \\ Departemen Medical Surgical Nursing , Stikes Panrita Husada Bulukumba ,Indonesia1 \\ Departemen Community and Family Nursing , Stikes Panrita Husada Bulukumba, Indonesia ${ }^{2}$
}

Corresponding Autor : safaryahya1@gmail.com*

\begin{abstract}
Nursing as a science that continues to develop, both due to external pressure and because of internal pressure nursing. One of the problems faced by Indonesian nurses in the health service system is the low standard of reward which can have an impact on nurse performance. The purpose of this study was to determine the relationship of rewarding with work motivation of nurses in the Inpatient Room of H. Andi Sulthan Daeng Radja Hospital in Bulukumba Regency, with total sampling taking 48 respondents. This research is a quantitative study using an analytic observational design using a cross-sectional study approach. The results of bivariate fisher analysis showed that the value of the $\mathrm{p}$-value was $0.028 \mathrm{p}(<0.05)$. The value of 0.028 is below the alpha value (0.05), thus there is a relationship between giving rewards with work motivation of nurses.Then it was concluded that there was a relationship between rewarding and work motivation for honorary nurses in the inpatient room of H. Andi Sulthan Daeng Radja Hospital in Bulukumba Regency. Based on the results of the study it is expected to the Hospital to provide more appropriate rewards or awards to improve better nursing services.
\end{abstract}

Keywords: Reward, Motivation

\section{INTRODUCTION}

The quality of nursing services as an indicator of the quality of health services is one of the determinants of the image of health care institutions in the eyes of the community, so the performance and motivation of nurses are always encouraged to be improved. This happens because nursing is the professional group with the highest number and is closest to the patient and his family. (Nursalam, 2014).

Minister of Health RI, dr. NafsiahMboi, Sp.A, MPH said that currently there are 220,575 nurses in Indonesia, with the majority of women. Based on the World Health Organization ratio the number of nurses in Indonesia is sufficient, but the problem that needs to be addressed is the distribution and quality of nurses. Therefore nurses should return pride to serve (pride to serve) in nurses (Ministry of Health RI, 2013). Nurses 
abroad One of the nurses in South Korea nurses are given a variety of facilities, facilities provided not only for working facilities but also for the personal needs of nurses on duty, such as homes. The room design and available facilities are arranged in such a way that it functions very effectively and efficiently. When compared with the conditions in Indonesia, this is still very different from the nursing system in Indonesia. Nurses in Indonesia do not yet have permission to practice independent nursing and rewards that have not adequate, the provision of adequate rewards and facilities for health workers on duty is another matter that should be considered. (Mediacom in the Indonesian Ministry of Health, 2010).

Nursing as a science that continues to develop, both due to external pressure and because of internal pressure nursing. One of the problems faced by Indonesian nurses in the health service system is the low standard of reward for nurses, especially nurses working in government agencies. This situation has an impact on the performance of nurses in implementing professional nursing care. (Nursalam, 2014). To increase employee motivation, companies or agencies often provide rewards or rewards for the performance achieved by individuals. These rewards can be financial (giving money, gifts) and non-financial (thanks, praise, and a good work environment). Reward in the form of financial right now is still in the top rank compared to non-financial. According to different opinions said that non-financial rewards are not as important as financial rewards. A thank you can be used as a reward. The power of this reward provides meaning and benefits that are extraordinary. Work that is motivated by an award from a superior to subordinates can be a source of inspiration for completing the work (Deni Kristinto \& Agus Santoso, 2013).

Based on Hermadi's research, 2014, with the title Research Factors relating to the work motivation of health workers in Suwawa Health Center Bone Bolango District, Gorontalo Prevention. Conclude that there is a relationship between appreciation and work motivation. The success of an effort and nursing service program is very dependent on the motivation of Dr. Supriyantoro (Ministry of Health 2012). Motivation is psychological which generates and directs behavior toward the achievement of goals or goal-directed behavior (Robert Kreitner and Angelo Kinicki, 2001: 2005 in Wibowo, 2012). Based on the results of a preliminary study by the author at H.Andi Sulthan Daeng Radja Hospital in Bulukumba Regency in 2016, there were 44 honorary nurses in charge in the inpatient ward of H. Andi Sulthan Daeng Radja Hospital in Bulukumba 
Regency. From the results of the interview of the writer with one of the heads of the room in H. Andi Sulthan Daeng Radja Hospital, Bulukumba Regency, financial rewards already exist, are given monthly and have been determined by the hospital management, but non-financial rewards are not always given. And from the results of interviews of the author with several honorary nurses, rewards in the form of financial and non-financial are not always given and rewards in the form of financials are always late given which makes nurses in doing their duties not full of motivation and affect their performance.

\section{MATERIAL AND METHODS}

Research design is a model or method used by researchers to conduct a study that gives direction to the course of research (Kelana, 2011). This type of research is a quantitative research using an analytic observational design using a cross-sectional study approach which is a research design that aims to determine the relationship between variables where the independent variable and the dependent variable are identified at the one-time unit (Kelana, 2011). In this study, researchers will describe the relationship of rewarding with Honorary Nurses' work motivation in the Inpatient Hospital of H.Andi Sulthan Daeng Radja, Bulukumba Regency. The population in this study were honorary nurses in the Inpatient Room of H.Andi Sulthan Daeng Radja Hospital, Bulukumba Regency with 44 honorary nurses. The sample is part of the population chosen as a representative of the whole to be investigated (Syamsuddin et al, 2015). In this study, the sample selection technique used by researchers is total sampling ie the entire population is sampled by researchers totaling 44 honorary nurses on duty in the inpatient room. The research instrument is a tool used by researchers to observe, measure or assess a phenomenon (Kelana, 2011).

The instrument used in this study was a questionnaire using a Likert scale to determine the relationship of reward giving with work motivation of honorary nurse nurses in the inpatient room of H. Andi Sulthan Hospital Daeng Radja Bulukumba Regency. Bivariate analysis is an analysis to find out the interaction of two variables, in the form of comparative, associative and correlative (Saryono and Anggraeni, 2013). Bivariate analysis in this study was conducted to determine the relationship between rewarding and work motivation of honorary nurses in the Inpatient Room of $\mathrm{H}$. Andi Sulthan Saeng Radja Hospital in Bulukumba Regency. Data obtained through observation sheets were analyzed using the Chi-Square Test with the help of the SPSS program. 
RESULTS

Table 1. Distribution of Frequency of Respondents by age of honorary nurse in the Inpatient Room

\begin{tabular}{lcc}
\hline Age & $\mathbf{n}$ & Percentage (\%) \\
\hline 24 & 5 & 10.4 \\
25 & 11 & 22.9 \\
26 & 16 & 33.3 \\
27 & 10 & 20.8 \\
28 & 4 & 8.3 \\
29 & 2 & 4.2 \\
\hline Gender & & 31,3 \\
\hline Male & 15 & 68,8 \\
Female & 33 & \\
\hline Length of working & & 14.6 \\
\hline$<2$ Year & 7 & 77.2 \\
$>4$ Year year & 37 & 8.3 \\
\hline Level Of Education & 4 & 27.1 \\
\hline DIII & & 10.4 \\
S1 & 30 & 62.5 \\
\hline Ners & 5 & 100.0 \\
\hline
\end{tabular}

From Table 1 it can be seen that of the 48 respondents, the lowest age frequency is 24 years as many as $5(10.4 \%)$ respondents, and the respondents with the highest age are 29 years as many as $2(4.2 \%)$ respondents and the majority of respondents aged 26 years are as many as 16 (33.3\%). For the characteristics of male sex which is 15 people (31.3\%), and those who are female as many as 33 people (68.8\%). For the characteristics of the working period $<2$ years, amounting to 7 respondents (14.6\%), 24 years working period as many as 37 respondents $(77.2 \%)$, and working period $>4$ years as many as 4 respondents (8.3\%). For the characteristics of DIII education which is 30 respondents $(27.1 \%)$, respondents with S1 education are 5 respondents $(10.4 \%)$ and respondents with nursing education are 13 (62.5\%).

Table 2. Distribution of Respondent Frequencies Based on the reward and motivation of honorary nurses in the room

\begin{tabular}{lcc}
\hline Reward & $\mathbf{n}$ & Percentage (\%) \\
\hline High & 32 & 66.7 \\
Low & 16 & 33.3 \\
\hline Motivation & & 83.3 \\
\hline High & 40 & 16.7 \\
Low & 8 & 100.0 \\
\hline
\end{tabular}

Based on table 2, it can be seen that the number of nurses who get high rewards is 32 people (66.7\%) and the number of nurses who get low rewards is 16 people $(33.3 \%)$. While motivation can be seen that the number of nurses who have high motivation is 40 people (83.3\%) and the number of nurses who have low motivation is 8 people $(16.7 \%)$. 
Table 3 Relationship of Rewarding with Honorary Nurse Work Motivation

\begin{tabular}{|c|c|c|c|c|c|c|c|}
\hline \multirow{3}{*}{ Reward } & \multicolumn{6}{|c|}{ Work motivation } & \multirow[t]{3}{*}{$P$ Value } \\
\hline & \multicolumn{2}{|c|}{ High motivation } & \multicolumn{2}{|c|}{ Low Motivation } & \multicolumn{2}{|c|}{ Amount } & \\
\hline & $\mathrm{f}$ & $\%$ & $\mathrm{f}$ & $\%$ & $\mathrm{n}$ & $\%$ & \\
\hline High & 24 & 50.0 & 8 & 16.7 & 16 & 33.3 & \\
\hline Low & 16 & 33.3 & 0 & 0 & 32 & 66.7 & 0.028 \\
\hline Amount & 40 & 83.3 & 8 & 16.7 & 48 & 100 & \\
\hline
\end{tabular}

The results of testing the hypothesis using the Fisher test showed a p value of 0.028 , when compared with an $\alpha$ value of 0.05 , the results were smaller $(0.05<0.028)$. This means that there is a significant relationship between rewarding with work motivation of nurses.

\section{DISCUSSION}

Based on the results of research conducted in the Inpatient Room of H. Andi Sulthan Daeng Radja Hospital in Bulukumba District, the results of 48 respondents were as many as 32 respondents who received high rewards (66.7\%), and the number of nurses who received low rewards was 16 people (33.3\%). The reward system model proposed by Kteitner and Knicks says that the purpose of an award is determined by three types of factors, namely the award norm, the type of award and the distribution criteria. The expected results or benefits that can be obtained from awarding are to attract, motivate, develop, and retain workers so as not to leave the organization. Meanwhile, the norm of appreciation is maximizing profits, providing justice, equality of behavior, and killing needs. The type of award consists of extrinsic elements and intrinsic elements. (Wibowo, 2012).

This study is in line with Winda J. Nangoi et al, (2014), with the research title Relationship Rewarding With Nurse Performance in the Irina A Room of RSUP Prof.DR. R. D. Kandou Manado. The results of 48 respondents showed that giving good rewards as many as 28 people (58.3\%), and good nurse performance as many as 37 people (77\%). The results of the bivariate chi-square correlation test results obtained p-value of $0.034 \mathrm{p}(<0.05)$. The value of 0.034 is below the alpha value of $5(0.05)$, thus there is a relationship between the provision of rewards and the performance of nurses in the Irina A room of RSUP Prof. Dr. R. D. Kandou Manado so it needs to be maintained and improved.

Researchers assume that the higher the award or reward given to nurses in performing nursing services, the better the nursing services will be provided to patients. Because 
with the provision of sufficient rewards will meet the needs of nurses so that nurses whose needs are fulfilled will be motivated at work.

Based on research conducted in the inpatient room of H. Andi Sulthan Daeng Radja Hospital in Bulukumba Regency it can be seen that the number of highly motivated nurses is 40 people (83.3\%) and the number of nurses who have low motivation is 8 people (16.7\%). From this study, it was found that the majority of respondents had high motivation and respondents who had low motivation, according to the researchers' assumptions this was due to lack of satisfaction at work caused by workplace environmental factors such as communication among fellow nurses. This is following the theory developed by Hinshaw, et al in his research finding factors supporting the motivation of nurses, namely the reduction of staff, professional status, enjoyment of positions held, group solidity, good working conditions and opportunities for professional growth. According to Abraham and Shanley revealed that there are several motivations of nurses to keep them working, namely satisfaction at work, a good work atmosphere, good managerial support, professional development and continuing education (Sunaryo, 2014).

The results of this study are in line with research conducted by Ferianus (2012), with the research title Honorary Nurses' Motivation Analysis in Providing Nursing Services to Patients in the Inpatient Room of the General Hospital Salewangang District, Maros Regency, South Sulawesi Prevention. The results of the study there is a relationship between relationships with colleagues in nursing services $(\rho=0.004<\alpha=$ 0.05). Ferianus assumes that the colleague in question is a cooperative relationship in the workplace environment such as a form of communication, the interaction between nurses, support between nurse friends and their leaders as well as mutual respect and mutual respect that can encourage carrying out their duties to create a pleasant atmosphere. The results of testing the hypothesis using the Fisher test showed a p-value of 0.028 when compared with an $\alpha$ value of 0.05 , the results were smaller $(0.05<0.028)$. This means that there is a significant relationship between rewarding with work motivation of nurses.

From the results of research conducted in the inpatient room of H. Andi Sulthan Daeng Radja Hospital in Bulukumba Regency, researchers assumed that 48 respondents had higher rewards with high motivation, namely 24 respondents (50.0\%). And respondents who have low rewards are high motivation as many as 16 respondents 
(33.3\%), and respondents who have high rewards but low motivation are 8 respondents (16.7\%).

From the results of the study, researchers assume that most respondents have high rewards and high motivation with 24 respondents (50.0\%), and there are still respondents with low rewards but have high motivation, as many as 16 respondents (33.3\%), this because the respondent did not make this a problem that could affect his motivation, the respondent focused more on the responsibilities given.

Financial rewards, whether in the form of salaries, wages, incentives or other benefits, are very popular. However, non-financial rewards, such as praise, acceptance, recognition, are no less important in improving employee performance. A survey that asked employees to give scores to various awards found that non-financial rewards were higher than financial rewards (Kaswan, 2012). Beyond wages, salaries, and incentives, leaders often provide additional income as an effort to better appreciate the performance of their workers. In other words, the management gives awards or rewards (Mulyasa in Andriani, 2013).This is in line with research conducted by Winda (2014) with the research title Relationship Rewarding With Nurses' Performance in the Irina A Room of RSUP Prof.DR. R. D. Kandou Manado. Chi-square bivariate correlation test results obtained p-value of $0.034 \mathrm{p}(<0.05)$. The value of 0.034 is below the alpha value of 5 (0.05), thus there is a relationship between the provision of rewards and the performance of nurses in the Irina A room of RSUP Prof. Dr. R. D. Kandou Manado.

The main purpose of giving rewards is to attract people to join the organization, keep employees coming to work, and motivate employees to achieve high levels of performance (Gibson \& Ivancevich in Wibowo, 2012). This is in line with Windy's research (2015), with the research title Relationship Between Service Rewards and Pearwat Work Motivation at Manganitu Health Center in Sangihe Regency. The results of the study using the Chi-Square Correlation Test obtained p-value $=0.003<\alpha=0.05$. The conclusion of the research shows that there is a relationship between service compensation and work motivation of nurses in the Manganitu Health Center in Sangihe District.

The ability to carry out tasks is a major element in assessing a person's performance. However, the task will not be finished well without the support of a will and motivation. If someone has done a good job, they will get satisfaction with the results achieved and challenges during the implementation process. This satisfaction 
can be created with a strategy to provide rigging, both in the form of physical, psychological and increased motivation. (Nursalam, 2012).

However, to grow the work motivation of each nurse, it is not as easy as expected. The problem is the leaders who encourage nurses to work vary and differ in ways from one another. This can be seen in one nursing unit, some nurses are diligent and diligent at work, are very productive, and have a high ability to complete tasks and responsibilities in providing nursing care. Conversely, some nurses are lazy, and lacking enthusiasm in working so that low work productivity. According to the researchers' assumptions, giving rewards is closely related to motivation. The higher the nurse's rewards, the higher the nurse's motivation at work to produce a good performance. Appropriate rewards in both financial and non-financial firms will encourage and motivate nurses to provide the best performance and produce optimal work productivity. Thus, when the Hospital wants good service for patients, the award given to honorary nurses must also be considered, so that nursing services provided by honorary nurses will be as desired.

\section{CONCLUSIONS}

There is a relationship between rewarding with work motivation of nurses in the inpatient room of H. Andi Sulthan Daeng Radja Hospital in Bulukumba Regency 1. For the Hospital to give rewards or more appropriate awards so as to improve better nursing services

\section{REFERENCES}

Andriani Susi.(2013). Penerapan Reward Sebagai Upaya Meningkatkan Motivsi Belajar Siswa Dalam Pembelajaran IPS IIIA di Min Tempel Ngalik Slemen. Di Terbitkan. Yogyakarta : Fakultas Tarbiah Dan Keguruan Universitas Islam Negri Kalijaga Yogyakarta

Budiman. (2013). Penelitian Kesehatan. Refika Aditama : Bandung.

Burhan, Windy Ira Sari, dkk. (2015). Hubungan Antara Imbalan Jasa Dan Motivasi Perawat Di Puskesmas Manganitu Kabupaten Sangihe. Program Studi Ilmu Keperawatan Fakultas Kedokteran Universiras Sam Ratulangi :jurnal

Dahlan, M. Sopiyuddin. (2014). Langkah-Langkah Membuat Proposal Penelitian Bidang Kedokteran Dan Kesehatan. Sagung Seto : Jakarta.

Dahlan, M. Sopiyuddin. (2014). Statistik untuk kedokteran. Dan kesehatan. Epidemiologi Indonesia: Jakarta 


\section{COMPRAHENSWEHABH CARE}

Depertemen Kesehatan RI. (2010). Mediakom. Diakses melalui http://perpustakaan.depkes.go.id:8180/bitstream/123456789/1718/2/Mediak om26-1010.pdf pada tanggal 9 februari 2016.

Departemen Kesehatan RI. (2012). Perilaku Caring Perawat. Diakses melalui http://www.depkes.go.id/article/print/1916/perilaku-caring-budaya-perawatindonesia.html. pada tanggal 17 januari 2016.

Dharma, Kelana Kusuma. (2011). Metodologi Penelitian Keperawatan (Pedoman Melaksanankan Dan Menerapkan Hasil Penelitian). Trans Info Media : Jakarta.

Haris, Haryanti, (2014). Hubungan Pemberian Reward Dan Beban Kerja Dengan Pelaksanaan Dokumentasi Asuhan Keperawatan Di Rumah Sakit Islam Faisal. Tesis diterbitkan. Makassar: Program Pasca Sarjana Universitas Hasanuddin Makassar.

Hermadi, Handayani Yati. (2014). Faktor-faktor Yang Berhubungan Dengan motivasi Kerja Tenaga Kesehatan Di Puskesmas Sewawa Kabupaten Bone Bolngo. Fakultas Ilmu Kesehatan Dan Keolahragaan Universitas Negeri Gorontalo: Jurnal

Kaswan. (2012). Manejemen Sumber Daya Manusia untuk keunggulan Bersaing Organisasi. Graha Ilmu: Yogyakarta.

Kementrian Kesehatan RI. (2013). Kebanggan Untuk Melayani Dalam Diri Perawat.DiaksesMelaluihttp://www.depkes.go.id/article/view/2251/menkeskembalikan-kebanggaan-untuk-melayani-dalam-diri-perawat.html Pada Tanggal 2 Februari 2016.

KNEPK. (2012). Etika Penelitian.

Koke, Ferianus Meitus, dkk. (2012). Analisis Motivasi Perawat Honorer Dalam Memberikan Pelayanan Keperawatan Pada Pasien Diruang Rawat Inap Ruma Sakit Umum Daerah Salewangang Kabupaten Maros Provensi Sulawesi Selatan. STIKES Nani Hasanuddin Makassar, Vol.1(4) Hal.1-8

Kuntoro Agus. (2010). Buku Ajar Manejemen Keperawatan. Medical Book Yogyakarta

Nangoi, Winda J, dkk. (2014). Hubungan Pemberian Reward Dengan Kinerja Perawat Di Ruangan Irina A RSUP Prof.Dr.R.D.Kandou Manado. Program Study Ilmu Keperawatan Fakultas Kedokteran Universitas Sam Ratulangi,Hal.1-7.

Notoatmodjo, S. (2011). Promosi Kesehatan Dan Ilmu Perilaku. Rineka Cipta : Jakarta. Nursalam. (2014). Manejemen Keperawatan. Salemba Medika : Jakarta 


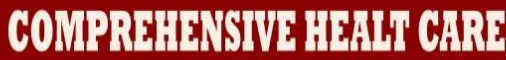

Saam, Zulfan., \& Wahyuni Sri. (2013), Psikologi Keperawatan. Rajawali Pers : Jakarta

Stikes Panrita Husada Bulukumba. (2016). Buku Pedoman Penulisan Skripsi.

Santoso, Agus \& Kristianto, Deni. (2013). Hubungan Pemberian Reward Ucapan Terima Kasih dengan Kedisiplinan Waktu Saat Mengikuti Timbang Terima Perawat Ruang Bedah Rs Negeri Semarang. Prodi Ilmu Keperawatan FIK Universitas Pekalongan, Hal. 1-14

Saryono., Anggraeni, Mekar Dewi. (2013). Metodologi penelitian kualitatif dan kuantitatif dalam bidang kesehatan. Nuha Medika: Yogyakarta.

Sugiyono. (2012).Metode Penelitian Kuantitatif dan Kualitatif dan R\&D. Alfabeta: Bandung

Sulfitrah. (2013). Hubungan motivasi kerja dengan tingkat kedisiplinan perawat dipuskesmas Balibo Kecematan Kindang kabupaten Bulukumba. Program studi Ilmu Keperawatan STIKES Panrita Husada Kabupaten Bulukumba. Tidak diterbitkan

Sunaryo. (2014). Psikologi untuk keperawatan Edisi . EGC : Jakarta

Syamsuddin, et.al., (2015). Pedoman Praktis Metodologi Penelitian Internal (Pendekatan Kualitatif, Kuantitatif, Pengembangan Dan Mix-Method), Wade Group : Ponorogo.

Wibowo. (2012). Manejemen Kinerja, ed. 3. Rajawali Pers : Jakarta. 